\title{
Phatic Communion in the Perspective of Language Dignity
}

\author{
R. Kunjana Rahardi \\ kunjana@usd.ac.id \\ Indonesian Language and Literature Education Study Program, Sanata Dharma University
}

\begin{abstract}
The efforts to dignify the Indonesian language must not stop at the elaboration of grammatical rules. The Indonesian grammatical rules have long been standardized but it is still debatable whether the Indonesian language has achieved its dignity or not. As a rule, the dignified language should carry the various functions which cater to several different interests and is learned by the wider audience. The formulation of rules interconnecting with language use as in the pragmatic studies must be promoted. Essentially, the linguistic study and pragmatic study of language have the same purpose despite their different manners of doing it.
\end{abstract}

Keywords: phatic expression, dignify, language functions, pragmatic phenomena

\section{Introduction}

In the monography entitled Kelas Kata dalam Bahasa Indonesia (Word Classes in the Indonesian Language) written in a bid to fulfill the Alexander von Humbolt research grant in Johann Wolfgang Goethe University, Frankfurt am Main, West Germany in 1985, Prof. Dr. Harimurti Kridalaksana affirmed that the phatic category was a relatively new invention in the Indonesian linguistics (2008, p. 120). It was true what the Indonesian renowned linguist had said as up to today there has been only a little research on phatic expressions. Undeniably, several papers on a similar topic were written. Some scientific studies were also conducted in the form of undergraduate thesis, graduate thesis, and dissertations. However, the quantity and quality of the study are far from being considered significant.

In anticipating the signs of low interest in the study, in the past one year the writer has been specifically investigating phatic expressions in the language, particularly those in the educational domain. In terms of a small number of references for phatic expressions, it is expected that the research on phatic expressions funded by the research grant from the Directorate of Research and Community Services, Kemristek, DIKTI, can be conducted successfully for three consecutive years and reference books on Indonesian phatic expressions will soon be published.

Discussions on phatic expressions are inseparable from the issues of language function and dignity. While Kridalaksana said that phatic categories function to initiate, sustain, and assert communication (2008, p. 114), Sudaryanto (1990, p. 95) affirms that the intrinsic function of language is to humanize human beings to live with and for others. In the writer's opinion, to live for and with other human beings, one must be first and foremost able and willing to communicate with others. In the discussions on the language functions which are interrelated with language status, either as a national or official language, the issue of language dignity has become essential 
to discuss, because the dignity of a language, or the lack of it, depends highly on and is determined by the beauty and eloquence of the word in serving its functions.

In the writer's opinion, the beauty and eloquence of the language in carrying out the functions are by the clarity and establishment of the language rules. The clear and established rules of language are nonnegotiable in order to raise the dignity of a language. Therefore, the prolonged efforts to standardize the language rules through various means, despite rejections and disloyalty from the language users in employing the language rules to produce utterance and to create exchanges, must be stirred up again through more effective strategies. Hence, the Indonesian language will not be a foreign language in its own country in the future to come.

In this brief note, the writer intends to elaborate the pragmatic phenomena, namely phatic function, in the constellation of functions and dignity of the Indonesian language. The unclear language rules and its limitation in sustaining the identity of semantic meaning referred to as 'the fuzziness of grammatical categories' by Leech (1982, p. 25), particularly related to the speaker's meaning, can be explained through this language study using a pragmatic approach.

\section{From Phatic Communion to Phatic Communication}

The term phatic communion was initiated by Bronislaw Kasper Malinowski, a Polish anthropologist who undertook an ethnographic work in Trobriand Islands, Melanesia in 1923. From his ethnographic study, the well-known anthropologist introduced two language functions, namely (1) pragmatic function and (2) magical function. The term 'phatic' is derived from the verb in Greek, which means 'to speak', while the term 'communion' means 'the creation of ties of union' (Abercrombie, 1998). Further, the term 'phatic communion' is understood as 'establishing an atmosphere of sociability rather than communicating ideas' (Mey, 2008, p. 673).
In Sudaryanto (1990, p. 33), the term "communion" refers to the "personal encounter phenomenon; a face-to-face encounter between two people." Thus, 'communion' is not the same as 'communication' which essentially means 'the transfer of information, ideas, thoughts', which is referred to as 'communication of thought,' by Abercrombie (1998). This prominent linguist affirms that language does not merely function as a means to communicate information, ideas, thoughts, but above all, it is a means to place 'others as equal.'

In the writer's opinion, the process to make someone equal as others is only possible when the addresser and addressee are able and willing to cooperate and to treat other people as equals. Thus, the cooperation to make others equal can only be achieved when there is an 'encounter' between them to cooperate. The writer's opinion is corroborated by Abercrombie (1998) that 'ties of the union' means union in encounter to build agreements.

Phatic communion, according to Richards et al. (1985, p. 214), is ' $a$ term used by the British-Polish anthropologist Malinowski to refer to communication between people which is not intended to seek or convey information but has the social function of establishing or maintaining social contact.' They assert that the main purpose of phatic communion is neither to 'seek information' nor 'to transfer information', but it aims to "establish and preserve sociability."

Consequently, the English utterance "How are you?" which is translated into Indonesian "Apa kabar?" is not necessarily meant to seek for the addressee's 'information' or 'news'. Similarly, in an encounter, someone greets 'Sehat-sehat saja Bapak!', the addresser does not necessarily seek information about the addressee's 'health condition,' but it is meant to merely 'build sociability' with the addressee. Therefore, it would be strange for a university student who addresses the lecturer in a campus lobby by greeting, 'Selamat pagi, Pak!' (Good morning, Sir!) and is responded curtly by the professor who says, 'Sudah siang kok pagi!' (It's noontime already!). 
The Javanese rural community is wellknown for their friendliness and they usually exchange pleasantries among neighbors, such as addressing the neighbor who is on her way to the market by saying, "Tindak peken, Bu!" (Are you going to the market?). In the same friendly manner, the phatic expression will be responded with an utterance "Injih! Monggo! (Yes, I am. See you later). Therefore, even though the addresser has already known that the addressee is going to the market, the friendly question still needs to be expressed to 'preserve sociability.' Someone who is not familiar with the importance of sociability will reply rudely, 'Orang jelas-jelas sudah tahu saya mau ke pasar kok malah tanya begitu?' (It is clear that I am going to the market. Why do you need to ask?). It would be strange to respond rudely to questions about his/her wellbeing to establish small talk or to maintain sociability by saying, 'Sehiiittttt! Orang jelas jalannya begini kok ditanya sehat-sehat saja!' (I am sooooooo healthy, you know? Can you see that I can walk just fine? Why do you ask whether I am healthy or not?)

In the previous studies, such as a study by Kridalaksana (2008, pp. 119-121), some phatic markers have similar forms as interjections. In an utterance and in a certain exchange, the phatic markers such as ' $a h$, eh, halo, ya' overlap with interjections. Some discourse markers are actually phatic markers, such as ' $m b o k$, deh, kek, tho, ding, dong, kan, kok', while some others are pure interjections such as 'aduh, idih, wah, aduhai, wahai, bah, ih, nah, syukur, astaga'. Understanding of the 'clearcut identity' and 'overlapping identity' is important as the clear identity and language structure will have great influence on the interpretation of linguistic forms.

In relation to that, as a rule, phatic communion has a communicative dimension, whereas interjection has an emotive dimension. Phatic communion is commonly used in spoken contexts and tends to be nonstandard in nature. Therefore, phatic communion is signaled by sociolect and regional dialects.

Further, it should be clear that the linguistic phenomena in the pragmatic domain are not the same as the linguistic phenomena in the linguistic domain. The intrinsic meaning in pragmatics must be interconnected with the pragmatic context, which essentially consists of sets of assumptions (Rahardi, 2015), both personal and communal. On the other hand, lingustic meaning is understood dyadically as proposed by Buhler and Revesz.

Linguistics does not involve the contextual dimensions in the form of sets of assumptions, which are defined by Parker (1986), Wijana (1996), and Rahardi $(2015 ; 2016)$ as triadic in nature (triadic meaning). The phatic phenomenon belongs to the linguistic entity with a triadic dimension.

Understanding the phatic intention as uttered by the addresser is impossible to be done if the focus is only on the linguistic markers. In the Javanese language, the form 'monggo' or 'sumonggo' in the utterance or exchange has various pragmatic meaning interpretations. This happens because the variety of pragmatic meanings is determined by the different assumptions which essentially underlie the contexts. Thus, interpreting the intention of 'monggo' is not first of all determined by the spatio-temporal contexts which involve the dimensions of time and place (Alan, 1986), or the social-societal contexts as elaborated by Hymes (1972), but it is determined by the different sets of assumptions being the essence of the pragmatic contexts proposed earlier by Rahardi (2016).

Similarly, in the Indonesian language, the forms 'Ayo, lah!' and 'Lha, ayo lah!' have different pragmatic meanings. Understanding the speaker's intention or the pragmatic meaning through speakers' exchanges guarantees the accuracy of interpretation than through the speaker's utterance. The reasons behind this are the breadth and width of the contexts, both linguistically (co-text) - either linguistic or paralinguistic in nature-and extralinguistically - either social, societal, situational or pragmatic, which will determine the accuracy of interpretation of the speaker's meaning or speaker's sense.

Linguists have not investigated phatic communion in the pragmatic perspective. Bousfield (2008) argued that there has been a discrepancy between the study of language impoliteness and language politeness since 
Fraser (1999) elaborated four major perspectives, namely: (1) the social norm review, (2) the conversational-maxim view, (3) the face-saving view, dan (4) the conversational contract view. It can be concluded that the study of linguistic phatic communion is left behind compared to studies on other pragmatic phenomena and it tends to be deserted by the language researchers.

Concerns over the low quantity of research on language phatic communion were expressed by Kridalaksana (2008) and hammered down by Rahardi (2015) that the study of phatic communion is one of the deserted pragmatic phenomena which needs to be promoted. This concern is in line with the previous explanation, in which the issues of phatic communion is closely related to the language functions. The phatic communion in the pragmatic perspective which tends to be deserted is the manifestation of language disfunction which is contradictory to the efforts to promote and optimize the language function to raise the language dignity.

\section{Ideas of Pragmatic Universal and Phatic Universal}

Pragmatics, in the writer's idea, has two clearcut dimensions, namely specific dimension and universal dimension. The pragmatic specific dimension shows to us that all aspects of pragmatic, such as the scope, the principles, the maxims, and the phenomena must apply specifically and specially. The existence of certain community and culture which is unique and specific in nature will automatically determine the manifestation and identity of the pragmatic form (Du Bois, 1998). The culture-specific Pragmatics brings impetus to pragmatic studies in the culturespecific dimensions (Leech, 1983), which leads to the pragmatic studies in the specific dimensions, called sociopragmatics.

The fundamental difference between the general pragmatic studies and the specific pragmatic studies in the specific social and societal contexts can be clearly seen. The general pragmatic studies must be based on the situational context which essentially consists of personal and communal sets of assumptions (Rahardi, 2015). Pragmatics within the social and societal contexts should be based not merely on the situational context but it must also involve the contexts in the social and societal dimensions, referred to as the indexical contexts (in Rahardi, 2015).

To illustrate, the utterance 'Sampunsampun, mboten sah repot-repot' (Please, no! Don't bother yourself with me' uttered by a Javanese guest is clearly 'culture-specific', in which culture is embedded in its meaning. Although a guest actually needs water in the hot and humid weather, as a rule, the utterance above is appropriately said to manifest politeness containing the dimension of phatic function. In the general pragmatic study, for instance, in respect to Grice's work on cooperative principles, particularly the maxim of quality, the above function is clearly in contradictory to the Grice's maxim of quality. In Grice's cooperative principles, such utterance is deemed to violate the maxim of quality because the maxim requires someone to say 'apa adanya' (be truthful) in order to honor the maxim of quality.

In line with the specific and universal dimensions of pragmatics (Du Bois, 1998), phatic functions evidently have the universal dimensions instead of specific ones. It is argued that it is undeniable that phatic functions are specific in nature because phatic functions are essentially culture-specific set against the specific social backgrounds. That being said, it is confirmed that in its latter dimension, phatic function is culture-specific. In the culture-specific dimension, the manifestation of phatic function in a given society and culture will be different from that in another culture.

In a community whose level of survival is low, such expression as 'silakan dimakan saja semua' (Please eat them all) does not always have a pragmatic force as manifested in its literal linguistic form. It is possible that the contrary happens, that is 'jangan dimakan semuanya' (Don't eat them all). This is true in the Javanese expression, such as 'dipun agem kemawon sandalipun' (Please wear the sandals) when the guest enters the living room, which does not necessarily mean to request the guest to keep wearing the sandals 
when entering the living room. On the contrary, what is actually meant is to signal the guests to leave the sandals outside the host's living room, especially when the living room is covered with beautiful carpet and shiny tiles.

Rahardi $(2006 ; 2016)$ mentioned that such society is a community living with a 'samudana' (ambiguity, insinuation) cultural background. It is clear that the speaker's intention in a specific social and cultural context is not sufficiently explained in a more general context, which is defined by Leech (1983) as speech situational context. The situational context dimension proposed by Leech (1983) does not accommodate the specificity and particularity previously mentioned in Rahardi (2016) and consequently, to study the pragmatics within the specific and unique dimensions, a combination of situational and socio-cultural contexts must be prepared, or what is mentioned previously as the indexical contexts.

The next question is: where is the universality of the phatic functions? The answer is that first, phatic function is not separated from the linguistic entity. The contexts being constituted to understand the speaker's intention in the study of phatic functions should be embedded, integrated, and inseparable from the identity of the language itself. Such contexts are called contextembedded in language (Du Bois, 1998). The embedded context in the language is not necessarily the same as the intralinguistic context or internal context commonly understood as co-text. The intralinguistic context or internal context, as a rule, precedes and/or follows a certain language form being understood to find the linguistic and semantic meanings. Unlike the co-text identity, 'integrated' or 'embedded' linguistic contexts are constituted in the linguistic signs, structure, rules, and process of the language.

In relation to this, $\mathrm{Du}$ Bois (2008) states that: '...rather, it concerns context imbedded in language-contextual implications located in linguistic signs, structures, rules, and processes.' Hence, the Javanese language has language forms of utterance in the phatic context such as 'selamat pagi' and 'pagi' or maybe shortened into ' $g i$ ', and each has a different implicature, which is defined as context-embedded in language. The emerging language manifestation shows different pragmatic meanings. The form 'selamat pagi' implies the 'normal' utterance, while the form 'pagi' implies an 'abnormal' intention, and lastly, the form ' $g i$ ' clearly implies a 'very abnormal' intention.

The elaborated linguistic forms and the restricted linguistic forms, which imply the variety of speaker's intentions, is one of the markers that phatic functions contain universal dimensions. This phenomenon can be found in many languages in the world. In English, the forms 'good morning' and 'morning' to greet definitely have different speaker's senses. Du Bois (2008) confirms that the most fundamental pragmatic universal is that all human language have pragmatics. In relation to that, it is suffice to say that all human languages have phatic phenomena. When pragmatic is culture-specific, phatic functions must also be unique and culturespecific.

Second, the phatic phenomena have the aspect of context dimensionality. One language applies a different dimensional aspect from another language. To illustrate, in Indonesian, there are several words to represent different interpretation of personal deixis. Address terms ' $d a b$ ' and 'cho' may have similarity in terms of dimensions of social distance. An expression 'mau ke mana, dab?' and 'mau ke mana, cho?' can be easily interpreted as having the same personal deixis referring to close social distance. Compared to the Javanese greeting 'badhe tindak pundi, Bapa?', the differences in the dimensionality interpretation between ' $d a b$ ', 'cho', and ' $b a p a$ ' shown in the excerpt above can be found in many languages. Speaking of phatic functions, keeping in mind that all languages have certain 'context dimensionality' in interpreting the linguistic meaning, as one of the pragmatic phenomena, phatic functions carry the context dimensionality as well.

The third is the grammaticality fact. In terms of pragmatic universality, Du Bois (2008) asserts that 'a key reason for the pervasiveness and centrality of pragmatic universals is that there exists a prominent mechanism for embedding 
pragmatic dimensions within the linguistic structure: grammaticization.' Pragmatics and grammaticality are in fact inseparable and closely intertwined. Pragmatics is not necessarily understood as the study of the external structure of language but the study is inevitably related with the internal structure of language. Suffice to say that certain linguistic forms determine the language's pragmatic meaning. However, the contrary is true that the pragmatic force and meaning determine the linguistic forms used by the speakers. The same goes with the phatic phenomena, in which the speaker's intention in using certain phatic functions will determine the linguistic forms. On the contrary, the linguistic forms used by a speaker determine the phatic pragmatic functions. All languages are identified to have phatic universality mentioned earlier.

Therefore, it is not automatically said that pragmatic is merely a context-bound, instead of context-free, study of language; and the contexts refer to the extralinguistic contexts. The understanding of the pragmatic issues which is focused on the extralinguistic contexts only will tend to mislead as it tends to oversimplification. To respond to this, Du Bois (2008) states that "Pragmatics in this sense cannot be reduced to extralinguistic, 'real world' knowledge, as something outside the domain of language; rather it concerns context embedded in language."

\section{Phatic Functions in the Tapestry of the Promotion of Language Dignity}

As discussed in the previous parts, a dignified language is among others the one which has clear linguistic rules. The rules are not only intertwined within the linguistic dimensions, but they must also intertwine with the extralinguistics. The clear rules allow language users to enjoy the ease of learning the language. The linguistic rules are codified through standardization. The extralinguistic rules are formulated in the regular concrete use in the society. When these have been done well, the extensive and pervasive use of language will be achieved. This means that the language may express various interests and intentions, functions and purposes.
Considering the aspects of language dignity, the writer asserts that Indonesian is qualified as a dignified language. The Indonesian language has clear linguistic rules. The Indonesian language carries various different interests and serves many functions, both as a national language and an official language. However, it does not mean that the efforts to dignify the language must end here. As mentioned previously, the study of phatic functions in the Indonesian language has not been widely conducted as it is considered a new field of study. It is thus urgent to investigate the matters in depth so that the usage rules of the pragmatic phenomena, i.e. phatic functions, will be discovered soon.

It is clear, thus, that phatic functions whose purposes are to initiate, sustain, and reinforce communication among the speakers and addressees are in line with the inherent language functions, namely being men and women for and with others. Being men and women for and with others mean being with others in a close encounter or, in the case of phatic functions, 'communion'. In the communion, communication takes place, even when the communication is not meant to transmit information but simply to break the ice.

In respect to this, Leech (1983) mentioned the maxim of phatic which governs that someone must avoid the silence. The avoidance of silence, or speaking incessantly is clearly in contradictory to the maxim of quantity which expects the speaker to give as much information as is necessary for their interlocutors to understand their utterances, but to give no more information than is necessary. The violation of the maxim of quantity can be overcome and explained by saying that if the avoidance of silence does not have a specific illocutive purposes, then it merely serves the functions of 'initiating, reinforcing, and sustaining' communication. Hence, it must be said that it does not violate the Maxim of Quantity in Grice's Cooperative Principles. 


\section{Conclusion}

As a conclusion, it must be asserted again that the efforts to dignify the Indonesian language cannot stop when the linguistic rules are described in terms of linguistic definition. The Indonesian grammatical rules have been specified and codified for a long time. Nevertheless, the debate remains in whether the Indonesian language has truly been a dignified language, or whether it has served so

\section{References}

Abercrombie, D. (1998). Phatic Communion in Mey, Jacob L. (ed.) Concise Encyclopedia of Pragmatics. Amsterdam: Elsevier.

Allan, Keith. (1986). Linguistic Meaning. London: Routledge \& Kegan Paul plc.

Coulthard, Malcolm. (1995). Advances in Spoken Discourse Analysis. New York: Rouledge.

Du Bois, J.W. (1998). Pragmatic Universals in Mey, Jacob L. (ed.) Concise Encyclopedia of Pragmatics. Amsterdam: Elsevier.

Greenfell, L. (1998). Nationalism and Language in Mey, Jacob L. (ed.) Concise Encyclopedia of Pragmatics. Amsterdam: Elsevier.

Hymes, Dell. (1974). Foundation in Sociolinguistics: An Etnographic Approach. Philadelpia: University of Pennsylvania Press.

Kridalaksana, Harimurti. (2008). Kelas Kata dalam Bahasa Indonesia. Jakarta: PT Gramedia.

Leech, Geoffrey N. (1983). The Principles of Pragmatics. Oxford: Longman Group Limited.

Ogden, C. K. dan I. A. Richards. (1923). The Meaning of Meaning: A Study of The Influence of Language upon Thought. New York: A Harvest Book. many different functions, or has it catered many diverse interests, or is it studied by a wide audience. In the writer's opinion, the linguistic rules intertwining with the language use as shown in the pragmatic phenomena need to be promoted continuously. The pendulum of language study which has swung to the linguistic issues related to usage, optimization of language functions, has become the right momentum to dignify the Indonesian language more perfectly.

Poedjosoedarmo, Soepomo. (2001). Filsafat Bahasa. Surakarta: Muhammadiyah University Press.

Rahardi, Kunjana. (2016). PRAGMATIK: Fenomena Ketidaksantunan dalam Berbahasa. Jakarta: Penerbit Erlangga.

Rahardi, Kunjana. (2005). Pragmatik: Kesantunan Imperatif Bahasa Indonesia. Jakarta: Erlangga.

Rahardi, Kunjana. (2015). Menemukan hakikat konteks. In Jatmiko et al. (Eds.). Kajian Pragmatik dalam Berbagai Perspektif (pp.17-22). Surakarta: Program Pascasarjana UNS.

Rahardi, R. K., Setyaningsih, Y., Dewi, R. P. (2015b). Kata fatis penanda ketidaksantunan pragmatik dalam ranah keluarga. Adabiyyat, 13(2), 149175.

Richards, Jack., John Platt, Heidi Weber (1985). Longman Dictionary of Applied Linguistics. London: Longman.

Sperber, Dan dan Deirdre Wilson. (1981). Relevance: Communication \& Cognition. New Jersey: Blackwell Publishers.

Sudaryanto. (1990). Menguak Fungsi Hakiki Bahasa. Yogyakarta: Duta Wacana University Press. 